Cette étude intra-matière première montre qu'il est possible de prédire la dégradabilité ruminale de l'azote du corn gluten feed avec une précision suffisante en utilisant à la fois des critères chimiques [cellulose brute, action du $\mathrm{pH}$ sans les enzymes (TE2)] et des critères biologiques [dégradabilité enzymatique (DE1)].

La solubilité enzymatique à $\mathrm{pH}$ ruminal (DE2) ne semble pas mieux prédire la DT6 que la solubilité par action du pH (TE2). Ceci montre que les corn gluten feed testés ont subi un traitement thermique modéré et que leurs protéines sont facilement accessibles. La prédiction de la dégradabilité des matières azotées totales des corn gluten feed par TE2 et la cellulose brute [2] présente l'intérêt d'être la plus précise et la moins coûteuse.

\section{Characterization of protein fractions of sunflower seeds during rumen degrada-} tion. R Nola ${ }^{1}$, S lametti ${ }^{2}, \mathrm{~F}$ Sessa ${ }^{2}, \mathrm{GF}$ Greppi 3, S Pagani 2 (1 Ist Zootec Gen, Milan; 2 Dip Sc Mol Agr Alim, Milan; ${ }^{3}$ Dipartimento di Scienze Anatomische, Fisiologische e delle produzioni animali, viale della Piagga, 2, 56121 Pisa, Italy)

The protein value of a feed utilized in polygastric nutrition depends on rumen degradation as well as on the amino-acid composition and digestibility of the undegraded proteins passing to the small intestine. The nylon-bag method is an effective tool for the prediction of rumen degradation, but further indications can be provided by investigating the rumen degradability of specific protein fractions. In this study we monitored the breakdown rates of sunflower-seed protein fractions during rumen incubation. The amino-acid composition of slowly degradable fractions was determined with the aim of correlating these polypeptide fractions with the level of microbial proteolysis in the goat rumen and the post-ruminal aminoacid availability

Sunflower seeds were incubated in goat rumen $(0,2,4,8,12,16,24,48$ and $72 h)$ and the protein fraction of the undegraded residues was solubilized. Samples from each ruminal incubation time and containing $20 \mu \mathrm{g}$ of nitrogen were electrophoresed on $15 \%$ polyacrylamide gel according to Laemmli. Fractional protein degradation was monitored by image processing. The slowly degradable polypeptides were transferred from the electrophoretic gel to a polyvinyldifluoride membrane and directly hydrolysed for amino-acid analysis.

Amino-acid analysis was performed by reversed-phase HPLC (C18) after derivatization with phenylthiocyanate. The protein fractions of apparent $M_{r}$ of $21,23,32,34,42$ and $57 \mathrm{kDa}$ showed different time-courses of degradability. None of these bands were detected by SDS-PAGE after $48 \mathrm{~h}$ rumen incubation. The 21 and $42 \mathrm{kDa}$ polypeptides showed the major resistance to rumen microbial proteolysis with respective degradation percentages of 3.6 and 24.5 after $2 \mathrm{~h}, 74.4$ and 54.4 after $8 \mathrm{~h}$, and 86.6 and 91.2 after $24 \mathrm{~h}$.

The relative amino-acid distributions of the 21 and $42 \mathrm{kDa}$ were the following: 30.4 and 22.4 hydrophobic residues, 0.6 and 2.3 cysteine, and 14.0 and 14.7 basic residues, respectively.

Our results show that the study of fractional protein degradation is an important task in order to find dietary protein fractions with higher rumen bypass. The amino-acid composition of sunflower seed 21 and $42 \mathrm{kDa}$ polypeptides indicated that slight amino-acid differences can be responsible for different susceptibilities to rumen microbial proteolysis.

\section{Effect of the rate of energy supply on nitrogen digestion in dairy cows fed a fresh forage diet. JL Peyraud, L Astigar- raga (Station de Recherches sur la Vache Laitière, 35590 Saint-Gilles, France)}

The digestion of high-nitrogen $(\mathrm{N})$ grass diets is characterized by a high rate of ammonia production and ruminal $\mathrm{N}$ losses. $\mathrm{N}$ could be used more efficiently if the rate of dietary energy supply and $\mathrm{N}$ release were synchronised.

The effects of supplementing white clover (42.5 $\mathrm{gN} / \mathrm{kg} \mathrm{DM}$ ) with wheat, whose rate of energy release matches ammonia production from white clover, or beet pulp (respectively 93 and $51 \%$ digestible OM (DOM) disappearing after $4 \mathrm{~h}$ incubation in sacco), on digestion were investigated in a cross-over design on 6 fistulated dairy cows (21 kg milk). Fresh grass was given ad libitum in 3 meals per day. Concentrates made up $30 \%$ of the diet and were distributed before the first and the last forage meals. Wheat straw $(500 \mathrm{~g} / \mathrm{d})$ was offered to prevent bloating. The flow of duode- 
nal digesta was calculated from PEG and $Y b$ recovered in faeces.

When feeding the pulp diet, total OM intake was higher $(14.1$ vs $13.1 \mathrm{~kg} / \mathrm{d}, P<0.10)$, OM digestibility was lower $(0.76$ vs $0.79, P<0.01)$, but DOM intake (DOMI, $10.5 \mathrm{~kg} / \mathrm{d}$ ), the proportion of DOMI that disappeared in the rumen $(0.66)$ and $\mathrm{N}$ intake (49 $\mathrm{g} / \mathrm{kg}$ DOMI) were not affected, compared to the wheat diet. Decrease of ruminal $\mathrm{pH}$ after a meal was less pronounced with pulp than with wheat $(-0.2$ vs -0.6 units, $P<0.05)$.

When feeding pulp diet, mean rumen ammonia was lower ( $171 \mathrm{vs} 250 \mathrm{mg} / \mathrm{l}, P<0.01)$, nonammonia nitrogen flow (NAN) was slightly higher (41.7 vs $37.2 \mathrm{~g} / \mathrm{kg}$ DOMl, $P<0.08$ ) and ruminal $\mathrm{N}$ losses were lower $(7.6 \mathrm{vs} 11.5 \mathrm{~g} / \mathrm{kg} D O M, P<$ 0.08 ) than with wheat diet. Urinary $N$ and milk $N$ output were not modified, since duodenal protein supply largely exceeded the animals requirements on both diets.

The efficiency of microbial synthesis did not vary $(27.7 \mathrm{~g} / \mathrm{kg}$ DOMI). Therefore, the difference in NAN flow could be ascribed to a higher flow of undegraded feed nitrogen when pulp diet was fed. This agreed with the lower protein degradability of the pulp diet $(0.79$ vs 0.84$)$ calculated from the in sacco degradabilities of feeds and assuming that carbohydrates did not modify the degradability of white clover.

The rate of energy supply in the rumen had only moderate effects upon $\mathrm{N}$ metabolism in dain cows fed fresh forage diets.

\section{Influence of the source of protein in the ration on the duodenal flow of amino acids in lactating dairy cows. JC Robert, BK Sloan, C Denis (Rhône-Poulenc Animal Nutrition, 03600 Commentry, France)}

Four mid-lactation Holstein dairy cows fitted with rumen and duodenal cannulae were offered diets of maize silage ad libitum plus 2 types of concentrate in a cross-over design experiment $(3 \times 3$ week-periods). Both concentrates contained equivalent quantities of wheat, barley, beet pulp and molasses $14,26,8.3$ and $5 \%$, respectively; in addition $A$ and $B$ contained, respectively: corn, 9 vs $6.9 \%$; soyabean meal (SBM), 4.5 vs $21 \%$; formaldehyde-treated SBM 29 vs $0 \%$; fishmeal, 0 vs $13 \%$; corn gluten meal, 1.5 vs $4.7 \%$; and urea 1.7 vs $0.1 \%$. A and $B$ were also designed to contribute similar quantities of duodenal lysine
(L) but larger quantities of methionine $(M)$ for diet $\mathrm{B}(\sim 5 \mathrm{~g})$.

Ytterbium acetate was continuously infused into the rumen. During each period a total collection of faeces was made between days 16 and 21 . Four samples of duodenal contents were collected each day between days 18 and 20 so as to give, on a daily basis, one sample for every $1 \mathrm{~h} 20 \mathrm{~min}$ from 06.00 to $20.40 \mathrm{~h}$. The samples were pooled for each cow for each period, lyophilised and analysed for ash, total $\mathrm{N}$ and $\mathrm{Yb}$; duodenal contents were also analysed for individual $A A$ (17) and DAPA. Nitrogen, apparent PDIN and PDIE intakes (g) were similar: 421 vs 426,1784 vs 1820 and 1 785 vs 1807 , for $A$ and $B$, respectively. Total duodenal flows of $N, A A, M$ and $L(g)$ were for $A$ and $B$, respectively: 416 vs 372 (SED 26), 2139 vs 1852 (SED 143), 35 vs 36 (SED 3.2), and 139 vs 124 (SED 8.3). Duodenal concentrations (as a mean of $17 \mathrm{AA})$ of $M$ were 1.6 and 1.9 (SED 0.10$)(p<$ 0.05 ) and of $L$ were 6.5 and 6.7 (SED 0.14), for diets $A$ and $B$, respectively.

An estimation of microbial nitrogen flow $(\mathrm{g})$ of 251 vs 211 for $A$ and $B$, respectively, relied on the assumption that the duodenal microbial N/DAPA ratio could be estimated from the ratio of the concentration of $\mathrm{N}(7.9 \% \mathrm{DM})$ to DAPA $(0.33 \% \mathrm{DM})$ in free rumen bacteria. Thus, the apparent efficiency of microbial protein synthesis was lower for diet $B$ than diet $\mathrm{A}: 13.8$ vs $20.6 \mathrm{~g}$ (microbial $\mathrm{N} \times 0.8 \mathrm{x}$ $6.25) / 100 \mathrm{~g}$ organic matter apparently digested in the rumen, masking a possible positive effect of $\mathrm{B}$ vs $\mathrm{A}$ on individual methionine flows.

Action des tanins hydrolysables sur la trypsine bovine. N Zimmer ${ }^{1}$, J Lafont ${ }^{2}$, R Cordesse ${ }^{1}$ ( 1 UZM, ENSA-INRA, 9, place Viala, 34060 Montpellier cedex $1 ; 2$ GBSA, USTL, place Bataillon, 34095 Montpellier cedex 5, France)

Les tanins, polyphénols présents dans de nombreux fourrages, peuvent soustraire des protéines alimentaires de la protéolyse par formation de complexes : s'agit-il d'un effet sur l'enzyme et/ou sur le substrat?

Pour répondre à cette question, nous avons suivi l'autolyse de la trypsine bovine et observé l'effet des tanins hydrolysables de châtaignier sur ce phénomène : sans tanins, la disparition de l'activité catalytique par autolyse se déroule selon un mécanisme d'ordre 2 dont la constante 